\title{
PENGEMBANGAN MODUL BERBASIS COOPERATIVE INTEGRATED READING COMPOSITION (CIRC) PADA MATERI PUJA DAN DOA DI SMK
}

\author{
Lusi Metasari $^{1}$, Prihadi Dwi Hatmono ${ }^{2}$, Sujiono ${ }^{3}$ \\ Sekolah Tinggi Agama Buddha Negeri Raden Wijaya \\ Wonogiri Jawa Tengah \\ lusimetasari1@gmail.com
}

\begin{abstract}
Abstrak
Tujuan dari penelitian ini menghasilkan produk berupa Modul pembelajaran agama Buddha pada materi puja dan doa. Modul puja dan doa berbasis Cooperative Integrated Reading Composition (CIRC) yang dikembangkan sangat layak untuk digunakan dalam proses pembelajaran. Berdasarkan penilaian ahli media diperoleh skor $91,7 \%$ dan penilaian ahli materi diperoleh skor 80,5\% masing-masing dengan kategori sangat layak, sedangkan hasil uji coba pengembangan menunjukan bahwa respon peserta didik terhadap kelayakan modul yang dikembangkan menunjukan kategori sangat layak dengan skor rata-rata sebesar $80,9 \%$ dan $93 \%$.

Kata Kunci: Modul, Pendekatan Cooperative Integrated Reading Composition (CIRC), Kelayakan Modul
\end{abstract}

\begin{abstract}
The purpose of this study is to produce a product in learning module ob puja material and prayer. The Cooperative Integrated Reading Composition (CIRC) based puja and prayer module developed is very worthy of use in the learning process. Based on the media experts'assessment the score is $91,7 \%$ and the assessment of the material experts scored $80,5 \%$ points each with a very reasonable category, whereas development tests suggest that the learners responses to the worthiness of the developed module suggest the category is highly viable of averaging $80,9 \%$ and $93 \%$.
\end{abstract}

Keywords: Module, CIRC approach, Module Feasibility. 


\section{PENDAHULUAN}

Kehidupan di era globalisasi yang semakin maju, pendidikan merupakan hal yang sangat penting bagi kehidupan bangsa. Pendidikan merupakan salah satu tolak ukur kemajuan suatu bangsa. Bekal pendidikan yang cukup dapat meningkatkan kualitas sumber daya manusia demi terwujudnnya cita-cita nasional dan pembangunan suatu bangsa dan negara. Diantara sekian banyak agenda pembangunan bangsa, dimulai agenda melakukan reformasi sistem dan penegakan hukum yang bebas korupsi, bermartabat, dan terpercaya,meningkatkan daya saing di pasar internasional, memperteguh kebinekaan dan memperkuat restorasi sosial Indonesia, meningkatkan kualitas hidup manusia Indonesia melalui peningkatan kualitas pendidikan dan pelatihan dengan program "Indonesia Pintar" dan melakukan revolusi karakter bangsa melalui kebijakan penataan kembali kurikulum pendidikan nasional dengan mengedepankan aspek pendidikan kewarganegaraan.

Menurut Rachman Anshari, (2012:1) di akses dari https://dikdaperenc.wordpress.com. Pendidikan merupakan salah satu agenda terpenting dan strategis yang menutut perhatian sungguh-sungguh dari semua pihak. Sebab pendidikan adalah faktor penentu kemajuan suatu bangsa di masa depan. Suatu bangsa berhasil membangun dasar-dasar pendidikan nasional dengan baik maka pendidikan diharapkan dapat berkontribusi terhadap kemajuan dibidang-bidang lain.
Pembangunan suatu bangsa dan negara akan berhasil apabila didukung oleh sumber daya manusia yang berkualitas. Sumber daya manusia yang berkualitas dapat dibentuk melalui pendidikan. Pendidikan yang cukup akan membantu manusia dalam menambah wawasan, pengetahuan, skill dan ketrampilannya serta dapat dipergunakan untuk membantu mewujudkan terlaksananya pembangunan bangsa dan negara. Hal tersebut sejalan dengan pengertian pendidikan menurut Undang-undang Republik Indonesia No. 20 Tahun 2003 tentang sistem Pendidikan Nasional, Pasal 1 yang menjelaskan bahwa :

"Pendidikan adalah usaha sadar dan terencana untuk mewujudkan suasana belajar dan proses pembelajaran agar peserta didik secara aktif mengembangkan kepribadian, kecerdasan, akhlak mulia, serta keterampilan diri, dirinya, masyarakat, bangsa dan negara"

Pendidikan memiliki peranan sangat penting untuk mempersiapkan generasi muda yang mampu bersaing dalam dunia yang semakin maju dan modern, di masa mendatang akan semakin banyak tantangan yang harus dihadapi oleh setiap manusia dalam dinamika kehidupannya. Pembangunan bidang pendidikan yang dilaksanakan oleh pemerintah bersama masyarakat merupakan upaya pelaksanaan salah satu cita-cita nasional, seperti yang tertuang dalam UUD 1945 anelia ke 4 yang salah satu 
berbunyi "mencerdaskan kehidupan bangsa". Salah satu bentuk proses pencerdasaan bangsa dilaksanakan melalui kegiatan pembelajaran.

Tujuan pendidikan nasional akan tercapai apabila ada usaha untuk meningkatkan mutu pendidikan. Hal tersebut perlu dilakukan karena pendidikan bersifat dinamis terus maju dan berkembang dalam setiap waktu, sehingga diperlukan perbaikan secara terus-menerus pada sistem pendidikan. Mutu pendidikan dapat diperbaiki melalui peningkatan kualitas guru, peningkatan materi, peningkatan dalam pemakaian metode dan peningkatan sarana (dalam kompasiana.com). Dari berbagai faktor pendukung untuk memperbaiki mutu pendidikan salah satu faktor yang terpenting adalah dengan perbaikan dalam kegiatan pembelajaran dan peningkatan sarana di sekolah. Berkaitan dengan hal tersebut, pemerintah telah melakukan upaya untuk meningkatkan kualitas pendidikan nasional, diantaranya pembaharuan kurikulum pembelajaran, peningkatan kualitas tenaga pendidik, penataan manajemen pendidikan serta penerapan teknologi informasi pendidikan. Dewasa ini, pemerintah telah melakukan salah satu upaya dalam meningkatkan kualitas pendidikan dengan pemberlakukan Kurikulum 2013.

Kurikulum 2013 merupakan kurikulum terbaru yang dikembangkan oleh pemerintah tahun 2013 dalam rangka memperbaiki sistem pendidikan yang ada dalam skripsi Lutfiah Endah F (2016: 2). Menurut Fadlilah (2014: 16), kurikulum 2013 adalah sebuah kurikulum yang dikembangkan untuk meningkatkan dan menyeimbangkan kemampuan Softskills dan hardskills yang berupa sikap, keterampilan dan pengetahuan. Dengan penerapan kurikulum 2013 diharapkan peserta didik memiliki kompetensi dalam sikap, ketrampilan dan pengetahuan jauh lebih baik mengenai apa yang diperoleh dan peserta didik ketahui selama proses pembelajaran di sekolah. Peserta didik akan lebih aktif dalam proses pembelajaran di sekolah karena kurikulum 2013 merupakan strategi yang bertujuan pembelajaran aktif bagi peserta didik di bandingkan guru.

Berdasarkan informasi di atas selaras dengan informasi yang diperoleh dari guru pendidik Agama Buddha di SMK 45 Wonosari Bapak Rukaman. Pembelajaran di SMK 45 masih belum efektif di karenakan terkaitnya keterbatasan pemahaman pada guru maupun peserta didik dan keterbatasan buku pembelajaran yang ada di SMK 45. Pembelajaran agama Budda di SMK belum menggunakan bahan ajar K13 secara penuh pada pembelajaran. Hasil wawancara yang telah dilakukan kepada Bapak Rukaman, Beliau menyatakan:

"Pembelajaran di sekolah secara keseluruhan cukup baik, materi yang terdapat dalam buku secara keseluruhan sudah baik, tetapi masih terdapat kendala dalam salah satu materi yaitu terdapat dalam materi Puja dan Doa. Dalam materi pembelajaran terdapat kendala kurangnya 
media pembelajaran dan terbatasnya waktu pembelajaran"

Bahwa di Sekolah tempat Beliau mengajar masih menemukan beberapa kendala dalam pembelajaran, kendala dalam bahan ajar berbasis K13 karena proses pembelajaran kebanyakan menggunakan KTSP dan kendala terdapat pada buku pembelajaran berbasis kurikulum 2013 yang masih berbasis online (hasil wawancara, 25 September 2018).

Kendala terkait pendidikan agama Buddha tidak hanya dikeluhkan oleh guru tetapi informasi diperoleh dari salah satu peserta didik. Peserta didik yang di ambil sebagai sampel penelitian merupakan peserta didik kelas XI dari peserta didik yang memiliki prestasi di atas ratarata dalam mata pelajaran agama Buddha. Peserta didik yang mendapat prestasi di atas ratarata masih mengalami kendala dalam mempelajari materi pembelajaran khususnya Puja dan Doa. Kendala yang di rasakan oleh peserta didik terdapat kebingungan dan ketidakpahaman pada materi terkait media, dan ilustrasi pada buku pelajaran yang ada (Evi murid kelas XI, 28 Oktober 2018).

Penulis mendapatkan data dari wawancara yang telah dilakukan, bahwa di SMK 45 belum menggunakan bahan ajar K13 secara penuh dalam pembelajaran, selain itu beberapa kendala yang terjadi dalam proses pembelajaran berbasis K13 khususnya pada materi Puja dan Doa, yaitu peserta didik mengalami kesulitan dalam belajar berbasis K13 terkait materi Puja dan Doa dikarenakan masih terdapat beberapa kendala seperti kurangnya contoh, gambar, dan ilustrasi, sehingga peserta didik timbul rasa kurang minat dalam belajar. Materi Puja dan Doa merupakan materi dasar dalam pembelajaran di kelas XI.

Materi Puja dan Doa merupakan salah satu materi sebagai pendoman atau cara yang dasar bagi murid sang Buddha melaksanakan ibadah dalam kepercayaannya. Melihat dari data atau fakta yang ada di lapangan penulis berencana melakukan pengembangkan modul tentang Puja dan Doa hal ini selaras dengan kesulitan-kesulitan peserta didik dan guru. Melihat materi Puja dan Doa sangat penting untuk di pahami dan di mengerti dengan benar dalam kehidupan peserta didik daripada materi pelajaran lain. Materi Puja dan Doa merupakan materi dasar melaksanakan praktik-praktik keagamaan dalam agama Buddha. Peserta didik dengan memahami materi Puja dan Doa diharapkan mampu melaksanakan praktik Dhamma/praktik keagamaan yang mencerminkan murid sang Buddha.

Sistem pembelajaran yang terjadi saat ini ialah terbatasnya pengembangan materi bahan ajar agama Buddha berbasis K13 dan kendala kemampuan guru dalam mengaplikasikan pembelajaran kurikulum 2013 yang masih keteteran khususnya pada materi Puja dan Doa. Apabila pembelajaran tersebut masih berlangsung dalam pendidikan agama Buddha maka akan berdampak pada peserta didik. Dampak yang terjadi antara lain: peserta didik menjadi kurang tertarik dalam proses 
pembelajaran, peserta didik kurang maksimal dalam hasil belajar materi Puja dan Doa, dan peserta didik tidak dapat memahami dan mempraktikan Puja Dan Doa sebagai murid sang Buddha dnegan benar. Hal tersebut tentu belum sejalan dengan cita-cita bangsa Indonesia seperti yang tertuang dalam Undang-Undang Dasar alinea ke-4 ialah "mencerdaskan kehidupan bangsa".

Melihat fenomena yang ada, sebagai upaya memperbaiki kualitas pemahaman peserta didik terhadap pembelajaran agama Buddha perlu dikembangkan suatu bahan ajar untuk mengajak peserta didik belajar membangun pengetahuannya sendiri melalui penyelesaian suatu permasalahan. Dalam hal ini, salah satu alternatif yang dapat ditawarkan adalah melalui pengembangan bahan ajar yang dapat dikembangkan salah satunya adalah dengan menggunakan Modul yang berbasis kurikulum 2013. Modul merupakan salah satu bentuk bahan ajar yang berbentuk media cetak. Menurut Syamsudin, (2005: 168), Modul merupakan bahan ajar cetak yang dirancang untuk dapat dipelajari secara mandiri oleh peserta pembelajaran. Modul disebut juga media untuk belajar mandiri karena didalamnya telah dilengkapi dengan petunjuk untuk belajar sendiri. Artinya modul bertujuan untuk melatih kemandirian belajar peserta didik melakukan kegiatan belajar tanpa kehadiran pengajar secara langsung.

Implementasi kurikulum 2013 bahan ajar berupa modul diharapkan dapat menjadi salah satu alternatif dalam melengkapi bahan ajar pada pembelajaran di kurikulum 2013, khususnya pada materi Puja dan Doa. Implementasi kurikulum 2013 selain berkendala dalam bahan ajar kendala juga berada pada guru. Penerapan kurikulum di sekolah guru belum menguasai mengaplikasikan kurikulum 2013 karena terkendala bahan ajar cetak di sekolah. Peserta didik mengalami kendala dalam pemahaman pembelajaran yang berlangsung. Melihat kondisi yang ada di lapangan modul pembelajaran doa dan puja sangat dibutuhkan sebagai pengenalan secara mendalam dan sekaligus pendamping kurikulum 2013 dan belajar mandiri peserta didik dalam memahami materi belajar.

Penelitian ini sesuai dengan penelitian Lasmiyati, dan Harta, I. (2014: 3), menjelaskan bahwa modul adalah salah satu bahan ajar yang menarik, mudah untuk dipelajari, dapat menjawab kebutuhan peserta didik, dan tentu dapat menimbulkan motivasi peserta didik untuk belajar. Berdasarkan hal tersebut maka pengembangan modul diharapkan dapat menjadi kontribusi dalam memperbaiki bahan ajar disekolah. Modul yang dikembangkan dirancang menggunakan pendekatan CIRC. "Pendekatan CIRC merupakan program komprehensif untuk mengajar membaca dan menulis pada sekolah dasar, pada tingkat yang lebih tinggi dan juga pada sekolah menengah" Madden, Slavin, dan Steven, (1986) dalam Slavin (2005: 16).

Pendekatan CIRC yang didalamnya terdiri dari kegiatan membentuk kelompok 
anggota empat orang secara heterogen, guru menyampaikan kompetensi yang ingin dicapai, guru memberi wacana sesuai dengan topik pembelajaran, peserta didik bekerja sama saling membaca dan menemukan ide pokok dan memberikan tanggapan terhadap wacana dan tertulis pada lembar kertas, mempresentasikan hasil kelompok, guru membuat kesimpulan bersama. Dengan modul yang akan dikembangkan, peserta didik diarahkan untuk memahami materi secara terstruktur melalui kegiatan memahami permasalahan yang telah di sajikan oleh guru atau topik yang ada dalam modul, peserta didik kemudian mencari dan menemukan solusi pada topik yang dibahas, dengan demikian peserta didik dapat lebih mandiri dan aktif untuk mengontruksi pengetahuannya melalui berbagai kegiatan yang dikembangkan di dalam modul yang sesuai dengan kurikulum 2013.

Berdasarkan uraian permasalahan diatas, bahwa penerapan kurikulum 2013 di sekolah masih adanya kendala pada proses pembelajaran. Meliputi peserta didik dan guru belum terdapat kesiapan dalam proses pembelajaran. Guru dan peserta didik masih mengalami kendala dalam pembelajaran berbasis K13 khususnya pada materi Puja dan Doa. Penulis terdorong untuk melakukan penelitian mengenai pengembangan bahan ajar yang berbasis pada kurikulum 2013 menggunakan pendekatan CIRC. Penggunaan pendekatan CIRC sebagai penawaran untuk melengkapi kendala yang terjadi dalam pembelajaran kurikulum 2013 dalam proses pembelajaran agama Buddha. Penulis terdorong melakukan penelitian mengenai pengembangan bahan ajar yang berbasis kurikulum 2013 dengan judul: "Pengembangan Modul Berbasis Cooperative Integrated Reading Composition (CIRC) Pada Materi Puja dan Doa” DI SMK.

Bahan ajar merupakan bagian penting dalam proses pembelajaran. Dalam suatu pembelajaran, bahan ajar dipergunakan oleh guru sebagai sarana untuk menyampaikan pengetahuan yang dimiliki oleh seorang guru kepada peserta didiknya. Tersediannya bahan ajar peserta didik dapat memahami materi pembelajaran, karena di dalam bahan ajar telah disajikan seraingkaian materi yang telah disusun secara sistematis sesuai dengan kompetensi yang harus dicapai atau dikuasai oleh peserta didik.

Menurut Depdiknas (2008: 4), bahan ajar adalah segala bentuk bahan yang digunakan untuk membantu guru/instruktur dalam melaksanakan kegiatan belajar mengajar. Bahan yang dimaksud bisa berupa bahan tertulis maupun bahan tidak tertulis. Menurut Prastowo (2014: 17) bahan ajar adalah bahan-bahan atau materi pelajaran yang disusun secara sistematis, digunakan guru dan peserta didik dalam proses pembelajaran. Schram (dalam Indriana, 2011: 14) menyatakan bahwa media pembelajaran merupakan teknologi pembawa pesan yang dapat dimanfaatkan untuk keperluan pembelajaran, sehingga media perluasan dari guru. Schram menyebut media pembelajaran 
sebagi perluasan guru, artinya guru memiliki perpanjangan tangan yang dapat membantu tersampaikannya pesan pembelajaran yang dibawakannya. Perpanjangan tangan guru tersebut berupa teknologi media pembelajaran, baik tradisional maupun modern. Apabila dipahami lebih lanjut maka hal ini sangat relevan dengan ajaran Buddha. Buddha dalam menyampaikan ajaran kepada muridnya juga menggunakan media yang dipilih secara tepat dengan menyesuaikan kondisi muridnya. Penerapan penggunaan media oleh Buddha dalam menyampaikan ajaran kepada muridnya dapat dipelajari berbagai dari sutta yang telah dibabarkan.

Pada zaman Sang Buddha, dalam Malika Sutta dikisahkan ada seorang Ratu bernama Ratu Malika yag memiliki kecantikan sangat luar biasa hingga kesombongan selalu menyertainya. Dengan kekuatan batin yang luar biasa, Buddha menyadarkan Ratu Malika dengan menciptakan penampakan visual yang menggambarkan proses kehidupan yang secara nyata adalah tidak kekal. Dari penampakan itu, kemudian Ratu Malika menyadari bahwa kecantikan yang dimiliki adalah tidak kekal. Dengan menyadari hal tersebut akhirnya Ratu Malika memperoleh pencerahan Batin (Bodhi, 2010: 235). Dalam Buddhajayamanggala Gatha, Buddha juga menunjukkan bagaimana menyadarkan sesosok naga Nandopananda yang memiliki kesaktian tinggi dan berpengertian salah.
Buddha meminta Y.A. Moggallana Thera untuk menaklukkannya dengan menjelma menjadi Naga dengan kesaktian yang dimilikinya (Dhammadiro, 2005: 111).

1. Bentuk-bentuk bahan ajar

Berikut ini dijelaskan berbagai macam bentuk bahan ajar menurut bentuknya yang dapat dikembangkan untuk proses pembelajaran menurut Prastowo (2014: 40), yaitu:

1) Bahan cetak (Printed), adalah sejumlah bahan yang disiapkan dalam kertas, berfungsi untuk keperluan pembelajaran atau penyampaian evaluasi. Contoh: buku, modul, lembar kerja peserta didik (LKS), brosur, handout, foto atau gambar, dan model atau maket.

2) Bahan ajar dengan program audio, yakni semua sistem menggunakan sinyal radio secara langsung, yang dapat dimainkan atau didengar oleh seseorang atau sekelompok orang. Contoh: kaset, radio, piringan hitam, dan compact disc audio.

3) Bahan ajar pandang (audiovisual), yaitu segala sesuatu yang memungkinkan sinyal audio dapat dikombinasikan dengan gambar bergerak secara sekuensial. Contoh: Vidio compact disc dan film.

4) Bahan ajar interaktif, yaitu kombinasi dari dua atau lebih media (audio, teks, grafik, gambar, animasi, dan vidio) 
oleh penggunanya dimanipulasi atau diberi perlakuan untuk mengendalikan suatu perintah atau perilaku alami dari suatu presentasi. Contoh: compact disc interactive.

2. Karakteristik Modul

Dalam panduan penulisan modul, agar menghasilkan modul yang mampu meningkatkan motivasi belajar, maka modul harus mencakup karakteristik yang diperlukan sebagai modul (Depdiknas, 2008: 3-5). Dengan demikian pengembangan modul bisa dikatakan baik apabila terdapat karakteristik sebagai berikut:

\section{1) Self Instructional}

Melalui modul tersebut peserta didik belajar mandiri, tidak tergantung pada pihak lain. Untuk memenuhi karakter self instructional, dalam modul harus terdapat:

a) Berisi tujuan yang dirumuskan dengan jelas

b) Berisi materi pembelajran yang dikemas ke dalam unit-unit kecil/ spesifik sehingga memudahkan belajar secara tuntas

c) Menyediakan contoh dan ilustrasi yang mendukung kejelasan pemaparan materi pembelajaran

d) Menampilkan soal-soal latihan, tugas dan sejenisnya yang memungkinkan pengguna memberikan respon dan mengukur tingkat penguasaannya e) Kontekstual yaitu materi-materi yang disajikan terkait dengan suasana atau konteks tugas dan lingkungan penggunanya

f) Menggunakan bahasa yang sederhana dan komunikatif

g) Terdapat rangkuman materi pembelajaran

h) Terdapat instrumen penilaian yang memungkinkan penggunaan diklat melakukan "self assessment"

i) Terdapat instrumen yang dapat digunakan penggunanya mengukur atau mengevaluasi tingkat penguasaan materi

j) Terdapat umpan balik atas penilaian, sehingga penggunanya mengetahui tingkat penguasaan materi, dan

k) Tersedia informasi tentang rujukan/ pengayaan/ referensi yang mendukung materi pembelajaran yang dimaksud.

\section{2) Self Contained}

Seluruh materi pembelajaran dari satu unit kompetensi atau sub kompetensi yang dipelajari terdapat di dalam satu modul secara utuh. Tujuan dari konsep ini adalah memberikan kesempatan pembelajar mempelajari materi pembelajaran yang tuntas, karena materi dikemas ke dalam satu kesatuan yang utuh. Jika harus dilakukan pembagian atau pemisahan materi dari satu unit kompetensi harus dilakukan dengan hati- 
hati dan memperhatikan keluasan kompetensi yang harus dikuasai.

3) Stand Alone (berdiri sendiri)

Modul yang dikembangkan tidak tergantung pada media lain atau tidak harus digunakan bersama-sama dengan media pembelajaran lain. Dengan menggunakan modul, pembelajar tidak tergantung dan harus menggunakan media yang lain untuk mempelajari atau mengerjakan tugas pada modul tersebut. Jika masih menggunakan dan tergantung pada media lain selain modul yang digunakan, maka media tersebut tidak dikategorikan sebagai media yang berdiri sendiri.

4) Adaptive

Modul hendaknya memiliki daya adaptif yang tinggi terhadap perkembangan ilmu dan teknologi. Dikatakan adaptif jika modul dapat menyesuaikan perkembangan ilmu pengetahuan dan teknologi, serta fleksibel digunakan. Dengan memperhatikan percepatan perkembangan ilmu dan teknologi perkembangan modul hendaknya tetap "up to date". Modul yang adaptif adalah jika isi materi pembelajaran dapat digunakan sampai dengan kurun waktu tertentu.

\section{5) User Friendly}

Modul hendaknya bersahabat dengan pemakainya. Setiap intruksi dan paparan informasi yang tampil bersifat membantu dan bersahabat dengan pemakainya, termasuk kemudahan pemakai dalam merespon, mengakses sesuai dengan keinginan. Penggnaan bahasa yang sederhana, mudah dimengerti serta menggunakan istilah yang umum digunakan merupakan salah satu bentuk user friendly.

3. Komponen Modul

Proses pengembangan bahan ajar khususnya modul, guru perlu memperhatikan prosedur dan komponen-komponen modul. Komponen-komponen tersebut meliputi tinjauan mata pelajaran, pendahuluan, latihan, rangkuman, evaluasi dan kunci jawaban, tindak lanjut dan daftar pustaka.

4. Prinsip Penulisan Modul

Mengembangkan media pembelajaran dengan menggunakan modul berarti mengajarkan suatu mata pelajaran melalui tulisan. Oleh karena itu prinsipprinsip yang digunakan dalam mengembangkannya sama halnya dengan pembelajaran biasa, bedanya adalah bahasa yang digunakan setengah formal dan setengah lisan, bukan seperti buku teks yang menggunakan bahasa formal. Terkait hal tersebut, menurut Depdiknas (2008: 9) penulisan modul dilakukan dengan menggunakan prinsip-prinsip antar lain sebagai berikut:

1) Peserta didik perlu diberikan penjelasan secara jelas hasil belajar yang menajdi tujuan pembelajaran sehingga peserta didik dapat menyiapkan harapan dan dapat 
menimbang untuk diri sendiri apakah peserta didik telah mencapai tujuan tersebut atau belum mencapainya pada saat melakukan pembelajaran menggunakan modul.

2) Peserta didik perlu diuji untuk dapat menentukan apakah peserta didik telah mencapai tujuan pembelajaran. Untuk itu, pada penulisan modul, tes perlu dipadukan ke dalam pembelajaran supaya dapat memeriksa ketercapaian tujuan pembelajaran dan memberikan umpan balik yang sesuai.

3) Bahan ajar perlu diurutkan sedemikian rupa sehingga memudahkan peserta didik untuk mempelajarinya. Urutan bahan ajar tersebut adalah dari mudah ke sulit, dari yang diketahui ke yang tidak diketahui dari pengetahuan ke penerapan.

4) Peserta didik perlu disediakan umpan balik sehingga mereka dapat memantau proses belajar dan mendpaatkan perbaikan bilamana diperlukan. Misalnya dengan memberikan kriteria atas hasil tes yang dilakukan secara mandiri.

Prosedur penulisan bahan ajar modul menurut Depdiknas (2008: 20) terdapat beberapa tahapan yang harus dilalui, yaitu:

1) Analisis SK dan KD

Analisis dimaksudkan untuk menentukan materi-materi mana yang memerlukan bahan ajar. Dalam menentukan materi dianalisis dengan cara melihat inti dari materi yang akan diajarkan, kemudian kompetensi yang harus dimiliki oleh peserta didik dan hasil belajar kritis yang harus dimiliki oleh peserta didik.

2) Menentukan judul-judul modul Judul modul ditentukan atas dasar KD$\mathrm{KD}$ atau materi pembelajaran yang terdapat dalam silabus. Satu kompetensi dapat dijadikan sebagai judul modul apabila kompetensi itu tidak terlalu besar, sedangkan besarnya kompetensi dapat dideteksi antara lain dengan cara apabila diuraikan ke dalam materi pokok mendapatkan maksimal 4 MP, maka kompetensi itu telah dapat dijadikan sebaai satu judul modul.

3) Pemberian kode modul

Kode modul sangat diperlukan guna mempermudah dalam pengelolaan modul. Biasanya kode modul merupakan angka-angka yang diberi makna, misalnya digit pertama, angka satu (1) berarti IPA, (2): IPS, (3) : Bahasa.

4) Penulisan Modul

Penulisan modul dapat dilakukan dengan langkah-langkah sebagai berikut:

a) Perumusan KD yang harus dikuasai

Perumusan KD pada suatu modul merupakan spesifikasi kualitas yang seharusnya telah dimiliki oleh peserta didik setelah berhasil menyelesaikan modul tersebut.

b) Menentukan alat evaluasi/penilaian 


Criterion items adalah
sejumlah pertanyaan atau tes yang
digunakan untuk mengetahui tingkat
keberhasilan peserta didik dalam
menguasai suatu KD dalam bentuk
tingkah laku. Karena pendekatan
pembelajarannya yang digunakan
adalah kompetensi, dimana sistem
evaluasinya didasarkan pada
penguasaan kompetensi, maka alat
evaluasi yang cocok adalah
menggunakan pendekatan Penilaian
Acuan Patokan (PAP).

5. Langkah pendekatan CIRC

Pembelajaran dengan pendekatan Cooperative Integrated and Composition (CIRC) memungkinkan peserta didik belajar lebih aktif bersama teman sekelompok dan menjadikan peserta didik menjadi aktif dalam pembelajaran. "Cooperative Integrated and Composition (CIRC) merupakan program komprehensif untuk mengajarkan membaca dan menulis pada sekolah dasar pada tingkat yang lebih tinggi dan juga pada sekolah menengah”, Madden, Slavin, dan Steven, (1986) dalam Slavin (2005: 16).

Berikut ini deskripsi langkahlangkah pendekatan CIRC pada pembelajaran:

1. Kegiatan membentuk kelompok beranggota 4-5 orang secara heterogen. Kelompok heterogen adalah terdiri dari campuran kemampuan peserta didik, perbedaan jenis kelamin, dan perbedaan suku maupun bahasa. Pembagian kelompok heterogen dimaksudkan untuk melatih peserta didik berlatih menerima perbedaan dan bekerjasama dengan teman yang mempunyai latar belakang berbeda.

2. Kegiatan Guru memberikan wacana/kliping sesuai dengan topik pembelajaran. Tahap pembelajaran ini guru mulai mengenalkan peserta didik tentang suatu konsep atau istilah baru yang mengacu pada hasil penemuan selama eksplorasi. Pengenalan bisa di dapat dari suatu bacaan baik melalui buku paket, atau media lain seperti ambil dari internet dan sebuah kliping. Dengan kegiatan ini peserta didik diharapkan dapat termotifasi untuk membuka ide-ide kreatifitasnnya menyelesaikan atau menanggapi suatu topik yang telah di siapkan oleh guru.

3. Peserta didik bekerjasama saling membacakan dan menemukan ide. Kegiatan pada tahap ini memberikan peluang pada peserta didik untuk mengungkap pengetahuan awalnya, mengembangan pengetahuan baru dan menjelaskan fenomena yang peserta didik alami dengan bimbingan guru minimal. Guru memberikan fasilitasi dengan minimal ketika peserta membutuhkan bantuan. Tahap ini menimbulkan terjadinnya konflik kognitif pada diri peserta didik, berusaha melakukan pengujian, dan berdiskusi menejlaskan 
hasil observasinya. Pada dasarnya tahap ini bertujuan untuk membangkitkan minat, rasa ingin tahu serta menerapkan konsepsi awal peserta didik dalam pembelajaran dengan dihadapkan permasalahan yang kogkrit. Selama tahap pembelajaran ini peserta didik melalui tindakan-tindakan mereka sendiri dan reaksi-reaksi dalam situasi baru yang masih berhubungan.

4. Peserta didik mempresentasikan hasil kelompok tahapan ini dilakukan agar peserta didik mampu mengkomunikasikan hasil temuan-temuan, membuktikan, memperagakan tentang materi yang di bahas dalam kelompok yang sudah terbentuk. Penemuan ini dapat bersifat sebagai gagasan barunya atau sekedar membuktikan hasil pengamatannya. Peserta didik dapat memberikan pembuktiaan tentang gagasan-gagasan yang telah ditemukan kepada teman-teman sekelasnya. Peserta didik siap menerima kritikan, saran dari teman sekelasnya atau sebaliknya saling memperkuat argumen.

5. Guru dan peserta didik memberikan kesimpulan bersama tahap ini peserta didik berserta guru mengambil kesimpilan bersama pada pembelajaran yang sedang berlangsung.

6. Penutup tahap penutupan guru beserta peserta didik mengakhiri pembelajaran.

6. Kerangka Berfikir

Pelaksanaan penelitian yang akan dilaksanakan pada bulan Maret untuk mempermudah hal tersebut dan mempermudah penelitian agar tidak menyimpang dari inti permasalahan maka perlu dijelaskan suatu kerangka pemikiran sebagai landasan dalam pembahasan. Adapun kerangka berfikir di gambarkan bagan sebagai berikut:

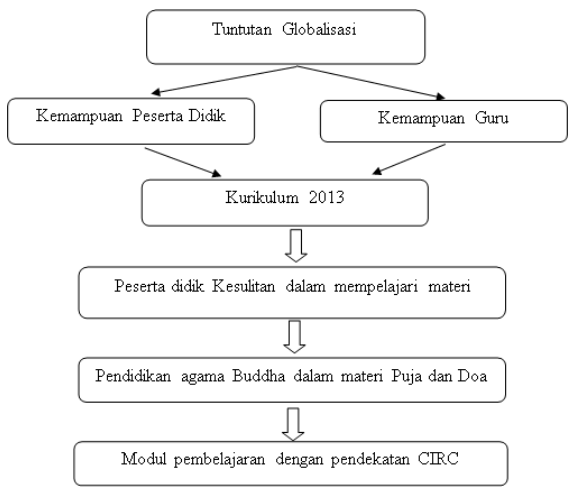

Gambar 2.1 Kerangka Berfikir Pengembangan Modul Berbasis CIRC

Perkembangan era globalisasi yang terjadi saat ini terpusat pada pendidikan dan teknologi. Perkembangan pendidikan dan teknologi berkembang dengan pesat baik dalam dunia pendidikan ataupun digital/teknologi. Perkembangan zaman yang semakin maju menuntut peningkatan kualitas dan kemajuan di dalam teknologi dan pendidikan. Khususnya peningkatan mutu dan kualitas yang terus selalu diupayakan dan setiap saat diperbaiki, dalam memperbaiki kualitas pendidikan di dalam Negeri. Perbaikan mutu dan kualitas memerlukan kemampuan peserta didik dalam selalu berkarya dengan prestasi-prestasi yang membanggakan dan mengharumkan Negeri 
Indonesia. Selain kemampuan dari prestasi gemilang anak bangsa kemampuan seorang guru juga harus mampu bersaing untuk mendapatkan segala ilmu yang akan di ajarkan kepada peserta didik dalam guna peningkatan kualitas pendidikan.

Peningkatan kualitas mutu pendidikan pemerintahan memberlakukan strategi dalam rangka meningkatkan mutu pendidikan yaitu dengan menerapkan kurikulum 2013 di semua jenjang pendidikan di Indonesia, tak terkecuali pada Sekolah Menengah Atas (SMA/SMK). Pengembangan Kurikulum 2013 sebagai upaya pemerintah untuk meningkatkan dan memperbaiki mutu pendidikan yang berguna untuk peserta didik guna memiliki softskill atau tiga ranah yaitu ranah kognitif, afektif dan psikomotor. Peserta didik di harapkan dengan diberlakukan pembelajaran berbasis kurikulum 2013 memiliki kecerdasaan secara intelektual, memiliki ketrampilan dalam sikap yang baik dan ketiga peserta didik diharapkan memiliki ketrampilan dalam mengaplikasikan ilmu - ilmu yang telah di pelajari dalam bangku sekolah.

Penerapan kurikulum 2013 sangat efektif dalam peningkatan mutu pendidikan di dalam negeri. Penerapan kurikulum 2013 menemui kendala, salah satunya yaitu dalam kendala media pembelajaran, buku kurikulum 2013 sudah terdapat dalam setiap sekolah khususnya agama Buddha tetapi dalam media pembelajarannya masih terdapat kendala- kendala yang perlu untuk di tambahkan atau di perbaiki guna memperbaiki mutu pendidikan agama Buddha khususnya dalam materi puja dan doa. Berdasarkan permasalahan tersebut, maka dirasa penting penelitian tentang pembuatan modul berbasis CIRC pada materi puja dan doa. Pengembangan Modul berbasis pendekatan CIRC pada materi puja dan doa dapat dijadikan suatu alternative dalam pemecahan permasalahan yang berkaitan dengan permasalahan yang terjadi di lapangan. Karena dengan pengembangan Modul berbasis CIRC diharapkan membantu peserta didik dan guru untuk memberikan bantuan mempermudah dalam aktivitas pembelajaran yang berlangsung. Tidak lupa penelitian ini diharapkan dapat mempermudah pemahaman peserta didik dalam belajar sehingga tercapainnya tujuan pembelajaran yang ingin dicapai.

\section{METODE PENELITIAN}

Pengembangan modul berbasis Cooperative Integrated Reading Composition (CIRC) menggunakan metode penelitian dan pengembangan (research and development). Penelitian dan pengembangan merupakan penelitian dengan hasil akhirnya berupa produk baru yang dapat digunakan dan disebarluaskan. Hal ini selaras dengan pendapat Sugiyono (2016: 297) bahwa penelitian dan pengembangan merupakan metode penelitian dengan tujuan untuk 
menghasilkan produk tertentu, dan menguji keefektifan produk tersebut.

Model pengembangan yang menjadi acuan penulis menurut Borg and Gall dalam Sugiyono (2015: 30). Menjelaskan terdapat beberapa langkah-langkah dalam model pengembangannya. Langkah-langkah dalam pelaksanaannya sebagai berikut:

1. Penelitian dan pengumpulan data (research and information collecting)

2. Perencanaan (planning)

3. Mengembangkan produk awal (develop preliminary form of product)

4. Uji coba lapangan awal (preliminary field testing)

5. Revisi produk utama (main product revision)

6. Uji coba lapangan utama (main field testing)

7. Penyempurnaan produk operasional (operational product revision)

8. Uji coba lapangan operasional (operational field testing)

9. Penyempurnaan produk akhir (Final product revision)

10. Deseminasi dan implementasi (dissemination and implementation)

Penelitian pengembangan ini merupakan penelitian dengan model prosedural, yang menunjukkan langkahlangkah dari proses pengembangan produk. Pengembangan produk dalam penelitian ini terbentuk modul pembelajaran. Media yang dikembangkan akan dinilai oleh ahli materi, ahli desain dan guru dan peserta didik sebagai pengguna modul pembelajaran. Sehingga diharapkan modul pembelajaran ini dapat dipergunakan dalam proses pembelajaran.

\section{HASIL DAN PEMBAHASAN}

Penelitian ini bertujuan untuk menyusun dan menghasilkan produk berupa Modul Pembelajaran agama Buddha pada materi Puja dan Doa berbasis pendekatan CIRC yang layak digunakan berdasarkan penilaian ahli media, ahli materi dan peserta didik sekolah yang menjadi sasaran penelitian.

1. Validasi Ahli Media

\begin{tabular}{|c|c|c|}
\hline $\begin{array}{c}\text { No } \\
\text { Butir }\end{array}$ & $\begin{array}{l}\text { Frekuensi } \\
\text { Observasi }\end{array}$ & $\begin{array}{c}\text { Frekuensi } \\
\text { Harapan }\end{array}$ \\
\hline 1 & 10 & 10 \\
\hline 2 & 8 & 10 \\
\hline 3 & 10 & 10 \\
\hline 4 & 10 & 10 \\
\hline 5 & 8 & 10 \\
\hline 6 & 7 & 10 \\
\hline 7 & 8 & 10 \\
\hline 8 & 10 & 10 \\
\hline 9 & 10 & 10 \\
\hline 10 & 8 & 10 \\
\hline 11 & 3 & 10 \\
\hline 12 & 6 & 10 \\
\hline 13 & 10 & 10 \\
\hline 14 & 10 & 10 \\
\hline 15 & 10 & 10 \\
\hline 16 & 10 & 10 \\
\hline 17 & 10 & 10 \\
\hline 18 & 10 & 10 \\
\hline 19 & 10 & 10 \\
\hline 20 & 10 & 10 \\
\hline
\end{tabular}




\begin{tabular}{|l|c|c|}
21 & 10 & 10 \\
\hline 22 & 8 & 10 \\
\hline 23 & 10 & 10 \\
\hline 24 & 10 & 10 \\
\hline 25 & 8 & 10 \\
\hline 26 & 10 & 10 \\
\hline 27 & 8 & 10 \\
\hline 28 & 10 & 10 \\
\hline 29 & 10 & 10 \\
\hline 30 & 10 & 10 \\
\hline 31 & 10 & 10 \\
\hline 32 & 8 & 10 \\
\hline 33 & 10 & 10 \\
\hline 34 & 10 & 10 \\
\hline 35 & 8 & 10 \\
\hline 36 & 10 & 10 \\
\hline 37 & 10 & 10 \\
\hline 38 & 10 & 10 \\
\hline 39 & 10 & 10 \\
\hline 40 & 8 & 10 \\
\hline 41 & 10 & 10 \\
\hline \multirow{2}{*}{ Jumlah } & $\mathbf{3 7 6}$ & $\mathbf{4 1 0}$ \\
\cline { 2 - 3 } & & $\mathbf{7 8 6}$ \\
\hline
\end{tabular}

Hasil dari validasi Ahli Media menunjukan persentase $91,7 \%$. Persentase $91,7 \%$ menunjukan kategori sangat layak dalam hasil validasi dari ahli media.

\begin{tabular}{|c|c|}
\hline $\begin{array}{c}\text { Persentase } \\
\text { Penilaian }\end{array}$ & Kategori \\
\hline$>81-100 \%$ & Sangat Layak \\
\hline$>61-80 \%$ & Layak \\
\hline$>41-60 \%$ & Cukup Layak \\
\hline$>21-40 \%$ & Tidak Layak \\
\hline $0-20 \%$ & $\begin{array}{c}\text { Sangat Tidak } \\
\text { Layak }\end{array}$ \\
\hline
\end{tabular}

2. Validasi Ahli Materi

\begin{tabular}{|l|c|c|}
\hline No Butir & $\begin{array}{c}\text { Frekuensi } \\
\text { Observasi }\end{array}$ & $\begin{array}{c}\text { Frekuensi } \\
\text { Harapan }\end{array}$ \\
\hline 1 & 7 & 10 \\
\hline 2 & 7 & 10 \\
\hline 3 & 9 & 10 \\
\hline 4 & 9 & 10 \\
\hline 5 & 9 & 10 \\
\hline 6 & 9 & 10 \\
\hline 7 & 10 & 10 \\
\hline 8 & 7 & 10 \\
\hline 9 & 8 & 10 \\
\hline 10 & 7 & 10 \\
\hline 11 & 8 & 10 \\
\hline 12 & 9 & 10 \\
\hline 13 & 9 & 10 \\
\hline 14 & 8 & 10 \\
\hline 15 & 8 & 10 \\
\hline 16 & 8 & 10 \\
\hline 17 & 7 & 10 \\
\hline 18 & 7 & 10 \\
\hline 19 & 9 & 10 \\
\hline 20 & 6 & 10 \\
\hline \multirow{2}{*}{ Jumlah } & $\mathbf{1 6 1}$ & $\mathbf{2 0 0}$ \\
\cline { 2 - 3 } & & \\
\hline
\end{tabular}

Hasil dari validasi Ahli Materi menunjukan persentase $80,5 \%$. Persentase $80,5 \%$ menunjukan kategori layak dalam hasil validasi dari ahli materi.

\begin{tabular}{|c|c|}
\hline $\begin{array}{c}\text { Persentase } \\
\text { Penilaian }\end{array}$ & Kategori \\
\hline$>81-100 \%$ & Sangat Layak \\
\hline$>61-80 \%$ & Layak \\
\hline$>41-60 \%$ & Cukup Layak \\
\hline$>21-40 \%$ & Tidak Layak \\
\hline $0-20 \%$ & $\begin{array}{c}\text { Sangat Tidak } \\
\text { Layak }\end{array}$ \\
\hline
\end{tabular}

3. Uji Coba Kelompok Kecil 


\begin{tabular}{|c|c|c|}
\hline $\begin{array}{c}\text { No } \\
\text { Butir }\end{array}$ & $\begin{array}{l}\text { Frekuensi } \\
\text { Observasi }\end{array}$ & $\begin{array}{c}\text { Frekuensi } \\
\text { Harapan }\end{array}$ \\
\hline 1 & 22 & 25 \\
\hline 2 & 20 & 25 \\
\hline 3 & 19 & 25 \\
\hline 4 & 20 & 25 \\
\hline 5 & 20 & 25 \\
\hline 6 & 17 & 25 \\
\hline 7 & 20 & 25 \\
\hline 8 & 18 & 25 \\
\hline 9 & 22 & 25 \\
\hline 10 & 19 & 25 \\
\hline 11 & 19 & 25 \\
\hline 12 & 20 & 25 \\
\hline 13 & 22 & 25 \\
\hline 14 & 21 & 25 \\
\hline 15 & 21 & 25 \\
\hline 16 & 21 & 25 \\
\hline 17 & 21 & 25 \\
\hline 18 & 22 & 25 \\
\hline 19 & 20 & 25 \\
\hline 20 & 21 & 25 \\
\hline 21 & 22 & 25 \\
\hline 22 & 21 & 25 \\
\hline 23 & 20 & 25 \\
\hline 24 & 18 & 25 \\
\hline 25 & 21 & 25 \\
\hline 26 & 19 & 25 \\
\hline 27 & 20 & 25 \\
\hline 28 & 21 & 25 \\
\hline 29 & 18 & 25 \\
\hline 30 & 20 & 25 \\
\hline 31 & 21 & 25 \\
\hline 32 & 20 & 25 \\
\hline 33 & 21 & 25 \\
\hline 34 & 20 & 25 \\
\hline 35 & 21 & 25 \\
\hline TOTAL & 708 & 875 \\
\hline
\end{tabular}

Hasil dari uji coba kelompok kecil menunjukan persentase $80,9 \%$. Persentase 80,9\% menunjukan kategori layak dalam hasil validasi dari uji coba kelompok kecil.

\begin{tabular}{|c|c|}
\hline $\begin{array}{c}\text { Persentase } \\
\text { Penilaian }\end{array}$ & Kategori \\
\hline$>81-100 \%$ & Sangat Layak \\
\hline$>61-80 \%$ & Layak \\
\hline$>41-60 \%$ & Cukup Layak \\
\hline$>21-40 \%$ & Tidak Layak \\
\hline $0-20 \%$ & $\begin{array}{c}\text { Sangat Tidak } \\
\text { Layak }\end{array}$ \\
\hline
\end{tabular}

4. Uji Coba Kelompok Besar

\begin{tabular}{|c|c|c|}
\hline $\begin{array}{c}\text { No } \\
\text { Butir }\end{array}$ & $\begin{array}{l}\text { Frekuensi } \\
\text { Observasi }\end{array}$ & $\begin{array}{c}\text { Frekuensi } \\
\text { Harapan }\end{array}$ \\
\hline 1 & 37 & 40 \\
\hline 2 & 37 & 40 \\
\hline 3 & 39 & 40 \\
\hline 4 & 38 & 40 \\
\hline 5 & 37 & 40 \\
\hline 6 & 36 & 40 \\
\hline 7 & 36 & 40 \\
\hline 8 & 35 & 40 \\
\hline 9 & 37 & 40 \\
\hline 10 & 38 & 40 \\
\hline 11 & 38 & 40 \\
\hline 12 & 37 & 40 \\
\hline 13 & 40 & 40 \\
\hline 14 & 39 & 40 \\
\hline 15 & 39 & 40 \\
\hline 16 & 38 & 40 \\
\hline 17 & 38 & 40 \\
\hline 18 & 36 & 40 \\
\hline 19 & 37 & 40 \\
\hline 20 & 38 & 40 \\
\hline 21 & 32 & 40 \\
\hline 22 & 39 & 40 \\
\hline
\end{tabular}




\begin{tabular}{|c|c|c|}
\hline 23 & 38 & 40 \\
\hline 24 & 35 & 40 \\
\hline 25 & 38 & 40 \\
\hline 26 & 37 & 40 \\
\hline 27 & 37 & 40 \\
\hline 28 & 35 & 40 \\
\hline 29 & 38 & 40 \\
\hline 30 & 37 & 40 \\
\hline 31 & 37 & 40 \\
\hline 32 & 37 & 40 \\
\hline 33 & 36 & 40 \\
\hline 34 & 39 & 40 \\
\hline 35 & 37 & 40 \\
\hline TOTAL & 1302 & 1400 \\
\hline
\end{tabular}

Hasil dari uji coba kelompok besar menunjukan persentase 93\%. Persentase 93\% menunjukan kategori sangat layak dalam hasil uji coba kelompok besar.

\begin{tabular}{|c|c|}
\hline $\begin{array}{c}\text { Persentase } \\
\text { Penilaian }\end{array}$ & Kategori \\
\hline$>81-100 \%$ & Sangat Layak \\
\hline$>61-80 \%$ & Layak \\
\hline$>41-60 \%$ & Cukup Layak \\
\hline$>21-40 \%$ & Tidak Layak \\
\hline $0-20 \%$ & $\begin{array}{c}\text { Sangat Tidak } \\
\text { Layak }\end{array}$ \\
\hline
\end{tabular}

\section{KESIMPULAN}

Berdasarkan hasil penelitian dan pembahasan, maka dapat diperoleh simpulan sebagai berikut.

1. Modul agama Buddha dengan pendekatan CIRC sebagai sumber belajar peserta didik kelas XI materi Puja dan Doa. Modul Puja dan Doa dikembangkan melalui tahapan yang dikembangkan oleh
Borg and Gall yang telah dimodifikasi oleh peneliti. Adapun tahapan yang dilalui, yaitu: (1) Studi Pendahuluan, melakukan obeservasi dan melakukan wawancara ke obyek penelitian (2) Pembuatan Produk Awal, membuat rancangan produk awal berupa rancangan modul pada materi puja dan doa (3) Validasi Ahli,produk sudah selesai dilakukan validasi ahli baik ahli materi ataupun media. Di lakukan validasi ahli untuk mengetahui valid tidaknya materi modul untuk di sebarkan di tempat penelitian (4) Uji Coba Kelompok Kecil, data yang diperoleh sudah bagus tetapi masuk banyaknya perbaikan pada materi modul maupun media dalam modul yang disusun (5) Revisi Produk Awal, revisi awal dilakukan untuk memperbaiki kekurangan-kekurangan yang telah ditemukan saat uji coba kelompok kecil (6) Uji Coba Kelompok Besar, dilakukan kepada seluruh obyek yang telah dipilih oleh peneliti, dilakukan uji kelompok besar diharapkan seluruh peserta didik dapat menerima dan mengerti pembelajaran yang telah disusun dalam modul (7) Revisi Produk Akhir dan Finalisasi, perbaikan terakhir dari hasil uji coba kelompok besar. 
2. Hasil penelitian menunjukkan bahwa modul pembelajaran ini secara keseluruhan sangat layak sebagai bahan ajar. Hal ini ditunjukan oleh hasil validasi ahli dan uji coba kelompok kecil dan uji kelompok besar oleh peserta didik. Hasil penilaian ahli media, modul pembelajaran ini dikatakan sangat layak dengan persentase $91,7 \%$. Hail penilaian ahli materi, modul pembelajaran ini dikatakan layak dengan persetase $80,5 \%$. Hasil penilaian dari uji coba kelompok kecil, modul pembelajaran dikatakan layak dengan persetase $80,9 \%$. Hasil penilaian uji kelompok besar, modul pembelajaran ini dikatakan sangat layak dengan persentase 93\%. Hasil tersebut dapat disimpulkan bahwa modul pembelajaran agama Buddha pada materi Puja dan Doa berbasis pendekatan CIRC ini sangat layak digunakan sebagai media pembelajaran pada mata pelajaran agama Buddha untuk peserta didik kelas XI di SMK 45 Wonosari, Kabupaten Gunungkidul.

\section{DAFTAR PUSTAKA}

Anshari, R. (2012). Pentingnya Pendidikan Bagi Pembangunan Sumber Daya Manusia. [Online]. Tersedia: https://dikdaperenc.wordpress.com. [23 November 2018], 20.00
Depdiknas. (2008). Panduan Pengembangan Bahan Ajar. Direktorat Pembinaan Sekolah Menengah Atas.

Depdiknas. (2008). Penulisan Modul. Jakarta: Direktorat Tenaga Kependidikan, Ditjen PMPTK, Depdiknas.

Fadlilah, M. (2014). Implementasi Kurikulum 2013 Dalam Pembelajaran $S D / M I, . S M P / M T s, \quad \& \quad S M A / M A$. Yogyakarta: PT Ar-ruzz Media.

Lasmiyati \& Harta, I. (2014). Pengembangan Modul Pembelajaran untuk Meningkatkan Pemahaman Konsep dan Minat SMP. Jurnal Pendidikan Matematika Volum 9. Hlm. 2-4.

Lutfiah Endah F, (2016). Pengembangan Lembar Kerja Siswa (LKS) Berbasis Pendekatan Saintifik Pada Pembelajaran Akuntansi Di SMK Negeri 1 Surakarta. Skripsi. Universitas Sebelas Maret.

Prastowo A. (2014). Panduan Kreatif Membuat Bahan Ajar Inovatif. Yogjakarta: Diva Press, Hlm.17- 40

Slavin. (2015). (Madden slavin dan Steven 1986). Digilib.unila.ac.id.

Sugiyono. (2015). Metode Penelitian \& Pengembangan Research and Development. Bandung: Alfabeta

Undang-Undang Sistem Pendidikan Nasional No. 20 Tahun 2003. 
Jurnal Pendidikan, Sains Sosial dan Agama

Undang-Undang Dasar. (1945). Anelia ke-4 